Article

\title{
Agricultural Biogas-An Important Element in the Circular and Low-Carbon Development in Poland
}

\author{
Arkadiusz Piwowar ${ }^{\mathbb{D}}$ \\ Department of Economics and Organization of Food Economy, Faculty of Economics and Finance, Wroclaw \\ University of Economics and Business, 118/120 Komandorska Street, 53-345 Wrocław, Poland; \\ arkadiusz.piwowar@ue.wroc.pl; Tel.: +48-71-36-80-430
}

Received: 17 March 2020; Accepted: 1 April 2020; Published: 5 April 2020

check for updates

\begin{abstract}
The agricultural sector can play an important role in the transformation of the energy economy in Poland. Special attention in this paper has been paid to the development of the agricultural biogas market in Poland. The considerations mainly concern organizational and economic aspects. Agricultural biogas plant represents the circular cycle of matter and energy. It enables the establishment of low-carbon, resource-efficient links between the agriculture and energy sectors. This is an important element of the circular economy, where waste from agricultural production and the agri-food industry, coming from renewable resources, is transformed into goods with a higher added value. The social and economic needs of the present generation and future generations are considered. The paper presented the characteristics of the Polish market, i.e., the number of entities, the number and location of plants, as well as the production volumes. Analyses were performed in the area of raw materials used to produce agricultural biogas. The analyses were carried out between 2011 and 2018. According to analyses, the potential of the agricultural biogas market in Poland is currently being used to a small extent. It is necessary not only to provide institutional support but also to increase the awareness of farmers and managers in agri-food companies of the possibility of using production waste for energy purposes.
\end{abstract}

Keywords: biomass; bioenergy; economics; sustainable development; rural area

\section{Introduction}

The modern village is not only a place of intentional plant cultivation and animal husbandry for food purposes but also an area with a much wider range of production and service activities. Activities in the field of substrate production and implementation of manufacturing and service processes in the energy sector are important from the concept of multifunctional development of rural areas, sustainable development, and transformation towards low-carbon development. Biogas, as an energy carrier can play an important role in low carbon energy transitions [1,2].

Agriculture in Poland is one of the main emitters of greenhouse gases. This is due to the relatively high animal production and the related problem of the disposal of animal faeces [3]. Poland is one of the leaders in the European Union in animal breeding (especially in poultry production) [4-6]. The intensive animal production is concentrated in the central, northern, and north-eastern parts of Poland [7]. The agricultural sector in Poland is the fourth largest emitter of methane and nitrogen oxide from agricultural production in the European Union [8]. Problems related to the protection of the natural environment in the aspect of the development of the agricultural economy in Poland are increasingly the subject of analyses in scientific works in the areas of technology, economics, and protection of the natural environment [9-12]. The challenges to be faced by Polish agriculture in the coming years result to a large extent from the need to reduce greenhouse gas emissions in connection 
with climate change. In general, this is important for assessing the achievement of the objectives of agricultural, energy, climate, and environmental policies [13-15].

In turn, agriculture and rural areas in Poland constitute a reservoir of renewable energy sources (RES) and an area for development in this scope [16]. There is a possibility for the development of photovoltaic and wind farms $[17,18]$. One of the opportunities for RES development in Poland is the production of agricultural biogas [19-22]. This is very important from many points of view. It provides, among other things, opportunities to increase the degree of independence from the imported energy supplies (mainly gas imports from Russia), enables diversification of supply sources, and creates conditions for the development of distributed power generation based on locally available raw materials. This is also particularly important in terms of achieving energy policy objectives. It is known that Poland will not be able to meet the objectives set for 2020 (i.e., 15\% share of renewable energy in the gross final energy consumption). The Ministry of Energy in Poland estimates that it is possible to achieve a $21 \%$ share of RES in the gross final energy consumption in 2030, which will be achieved successively by reaching $15 \%$ in 2022 , then approximately $17 \%$ in 2025 , and about $19 \%$ in 2027. The document "National Energy and Climate Plan 2021-2030", submitted and adopted by the Committee for European Affairs at its meeting on 18 December 2019, also sets a target of $23 \%$ in 2030. Still, it will only be possible to achieve if Poland is granted additional EU funds, including funds intended for a fair transformation [23].

Given the specific situation of Poland in the scope of the energy economy (approximately $80 \%$ of energy comes from non-renewable sources: hard coal and lignite), opportunities for low-carbon development are seen in increasing the production of biogas, including agricultural biogas. Coal power plants are also significant parts of Germany's and the Czech Republic's energy mix [24-26]. On the other hands, in recent years, there has been a rapid development of biogas energy generation in many European and South-East Asian countries [27-29]. The number of biogas plants in Europe has greatly increased. The total number of biogas plants rose from 6227 to 18,202 installations $(+11,975$ units) between 2009 and 2018 [30]. More than $70 \%$ of the EU biogas plants for electricity must operate on agriculture feedstock [31]. The biogas from anaerobic digesters is dominant in Germany, Italy, Denmark, Czech Republic, Austria, and Greece [31-33]. The leader in the agricultural biogas market in Europe is Germany, where an appropriate financial policy enabled an increase in the number of plants from 50 to 2279 in the period from 1999 to 2010 [34]. Between 2000 and 2003, the number of biogas plants in Germany increased from 850 to 1750 [35]. Despite a well-developed market in the examined scope, Germany is also looking for innovative paths of development in the context of including biogas plants in the bioeconomy system [36]. Moreover, in the Czech Republic, the biogas market has been developing rapidly. The total number of biogas plants in this country has increased from a few to 600 (where the total capacity of electricity generation of the plants exceeds $360 \mathrm{MW}$ ) [37].

Poland also has vast potential in this area. The organizational and technical potential of biogas produced only from livestock manure in Poland, depending on the adopted variant of technological parameters, ranges from 398.7 (realistic variant) to 1379.6 million $\mathrm{m}^{3} /$ year (hypothetical variant) [8]. The biogas potential for animal manure in Poland was estimated at 6.4 billion $\mathrm{m}^{3}$ [38-40]. In 2009, the Ministry of Agriculture and Rural Development in Poland presented a programme for the development of this market, where it was planned to build 2500 agricultural biogas plants with a capacity of 2000-3000 MW by 2020. The Ministry of Agriculture and Rural Development in Poland prepared assumptions for the Agricultural Biogas Plant Development Programme, constituting a proposal from the Minister of Agriculture and Rural Development that was submitted to the Minister of Economy for the needs of the "Innovative Energy Sector, Energy Agriculture" programme. Has this goal been achieved? How many agricultural biogas plants currently operate in Poland? What raw materials are used to produce agricultural biogas in Poland? Analyses in this area were carried out and presented in this paper.

The main purpose of this research was to characterize the agricultural biogas market, as well as present the historical background and current level of development. An additional goal was to 
identify the changes and development dynamics of this energy sector, along with an indication of further potential opportunities for development. To this end, a comparative analysis of the statistical data regarding the number of entities involved in biogas production, their location and the volume of production was carried out. Special attention was paid to the analysis of raw materials used for biogas production in Polish biogas plants. The main time range of the analyses was from 2011-2018.

One of the main priorities for the development of the energy sector in Poland in the coming years will be the development of distributed generation. In this context, the production of agricultural biogas is one of the most future-oriented directions of the distributed generation among renewable energy sources. Plants producing agricultural biogas, in which plant biomass, animal faeces, and organic waste from the agri-food industry are used to produce valuable goods (the value of waste is maximized), constitute an important element of the bioeconomy. The generation of energy from renewable sources and its use are important components of sustainable development. This is particularly important in terms of achieving long-term economic and environmental objectives.

This paper consists of a theoretical part and an analytical part. In the first part, the characteristics of agricultural biogas plants in the context of the development of the circular and low-carbon economy are presented. Then, the agricultural biogas market in Poland, with emphasis put on organizational and economic issues, are described. Finally, the conclusions and recommendations in the examined subject area are presented.

\section{Agricultural Biogas Market in the Context of Circular and Low-Carbon Development}

The circular economy is a departure from the linear model. This economy is based on the reuse of waste, which should translate into a sustainable, low-carbon, and resource-efficient economy. Agriculture has a special place in the circular economy (waste from plant and animal production, waste from farmers' households), while organic waste can be used as feedstock for energy production. In this context, biogas production is one of the most attractive forms of obtaining electricity and heat [41-43].

Many reasons justify the development of distributed energy generation in Poland. Generation of energy in a distributed system (distributed energy generation) has advantages in the technical, organizational, and economic areas. The Polish energy sector is based mainly on inefficient coal-fired blocks [44-46]. Currently, most of the energy produced in Poland comes from conventional fuels such as hard coal, lignite, natural gas, or crude oil. The share of renewable energy carriers in the total energy consumption in Poland was $8.2 \%$ in 2018 [47]. Poland has one of the highest levels of emission of carbon dioxide in Europe in relation to the electricity produced $\left(773 \mathrm{~g} \mathrm{CO}_{2} / \mathrm{kWh}\right.$ in 2016) [48].

Furthermore, the system is characterized by an overhead, mostly depreciated and inefficient power grid, especially in rural areas [49]. The development of energy generation based on distributed energy sources is a favourable solution from the economic point of view. This is due to cost reductions linked to energy transmission and the load on the transmission networks. Other advantages considered within the area of social sciences, including entrepreneurship and cooperatives, are also important. The functioning of elements of a distributed energy generation system in rural areas, including agricultural biogas plants, can be a lever for the economic and social progress. Agricultural biogas plants are part of a regenerative economic system, in which waste from some processes is used as feedstock for others.

Agricultural biogas plants perform many economic, environmental, and social functions essential for the development of the low-carbon and circular economy.

The production of agricultural biogas is an opportunity to generate additional income for the rural population-not only for producers of raw materials but also for people involved in the storage and transport of biomass [50]. The functions and economic benefits associated with the development of the agricultural biogas market can be analysed at various levels: macro-, meso-, and microeconomic. From a macroeconomic point of view, the impact of the activities associated directly (agricultural biogas producers) and indirectly (e.g., collection and transport of substrates to biogas plants) with biogas production on the revenues of the state budget and local government budgets is significant. The funds obtained for the state budget and local government budgets come from income tax (CIT (Corporate 
Income Tax), PIT (Personal Income Tax)) and turnover tax (VAT). Pursuant to Articles 23 and Art 24 (1) of the Act of 20 February 2015 on RES (Journal of Laws 2017, item 1148, as amended), business in agricultural biogas production conducted in RES plants other than micro scale agricultural biogas plants is a regulated activity. This is within the meaning of the Act on Freedom of Economic Activity and requires an entry in the register of agricultural biogas producers kept by the General Director of the National Support Centre for Agriculture. The current rate of stamp duty for making an entry in the register is PLN 616 (i.e., approximately EUR 140).

The economic and social functions of agricultural biogas plants, relevant for the development of the low-carbon economy, include:

- Additional opportunities for farmers to manage waste from agricultural production, which also allows reductions in the volume of bio-waste.

- Improvements in the efficiency of residues management from plant and animal production and waste from industrial processing of agricultural raw materials.

- Development of low-carbon energy sources in rural areas-biomass production on wasteland, etc.

- The modernization of road and storage infrastructure in rural areas.

- Development of distributed energy generation based on local energy resources.

- Improvement in the energy self-sufficiency of agricultural holdings.

- Additional sources of income for farmers and rural residents.

- Promoting the use of energy from renewable sources among residents of rural areas.

From an economic point of view, biogas production has many advantages. Local and regional development opportunities, including the creation of new jobs in rural areas, are particularly important. In addition,, agricultural biogas plants can be an asset in terms of image for the areas in which they operate. These areas can be perceived as modern and friendly to new technologies. This may attract further investments, including "green" ones. An important element in social factors is the education of residents of rural areas. An idea of creating educational centres and premises at biogas plants seem to be an interesting solution. Such a solution was proposed for the planned biogas plant in the village of Golina [51].

From environmental functions and benefits, it is worth emphasizing that the development of agricultural biogas plants is an important element of the process of recycling organic waste into fertilizer products (digestate as fertilizer) [52]. An important aspect of the operation of biogas plants in the context of the environment is the reduction of gas emissions generated during storage of liquid manure, as well as a reduction in emissions of odour substances. Biomethane has a lower carbon footprint than natural gas as it is derived from organic waste [53].

The issue of managing environmentally harmful waste is important in terms of the functions of agricultural biogas plants. Methane fermentation and other processes taking place in agricultural biogas plants protect the natural environment by reducing the carbon and methane emissions that contribute to the greenhouse effect $[27,54]$. The utilization of organic matter for the needs of biogas production reduces its uncontrolled decomposition that results in greenhouse gas (GHG) emissions. Curkowski et al. emphasize that $1 \mathrm{MWh}$ of electricity produced from agricultural biogas causes several times fewer emissions of basic air pollutants (mainly sulphur dioxide and nitrogen compounds) than the same energy produced from fossil fuels [55]. Sulewski et al. show that the use of natural fertilizers for energy production in Poland would reduce emissions of greenhouse gases from agriculture by $17.4 \%[38]$.

Apart from the positive impact on the soil and water environment and the atmosphere, the possible unfavourable elements in the rural environment are also important in the discussed subject area [56,57]. The issues of compositional and architectural elements of agricultural biogas plants in the agricultural landscape were presented in Pawłowski's study [51]. The agricultural biogas plant, as a new form of rural development, should be designed following the spatial order and the cultural identity of rural areas. Agricultural biogas plants possibly can also cause excessive nuisance (e.g., 
odour from tanks and silos where substrates are kept). The problem to the environment may also result from increased traffic of vehicles transporting substrates [58,59].

\section{Current Status and Development Opportunities of the Agricultural Biogas Market in Poland-Production Volume, Feedstock, and Economic Conditions}

The development of the biogas market in Poland is linked closely with the natural, legal, and economic conditions (feedstock for production, administrative decisions on the location of biogas plants, prices of green certificates and other forms of support for biogas production, costs of investments in technical infrastructure, etc.). The decision to build an agricultural biogas plant should be preceded by detailed analyses concerning, inter alia, the quantity and quality of available substrates, the possibility of obtaining methane from them, and the economic efficiency of the entire project [21,60-63].

In the years 2011-2018, high dynamics of changes in the volume of agricultural biogas production were recorded in Poland (Table 1).

Table 1. Basic data were characterizing the number of entities dealing with the production of agricultural biogas in Poland in 2011-2018 and the volume of this production [64].

\begin{tabular}{ccccc}
\hline Year & $\begin{array}{c}\text { The Number of } \\
\text { Entities Entered } \\
\text { into the Register }\end{array}$ & $\begin{array}{c}\text { The Number of } \\
\text { Plants Included in } \\
\text { the Register }\end{array}$ & $\begin{array}{c}\text { The Amount of } \\
\text { Agricultural } \\
\text { Biogas Produced } \\
\text { (thousand } \mathbf{~}^{\mathbf{3}} \text { ) }\end{array}$ & $\begin{array}{c}\text { The Amount of } \\
\text { Electricity } \\
\text { Generated from } \\
\text { Agricultural } \\
\text { Biogas (MWh) }\end{array}$ \\
\hline 2011 & 4 & 8 & 36,646 & 73,433 \\
\hline 2012 & 10 & 16 & 73,152 & 141,804 \\
\hline 2013 & 21 & 28 & 112,412 & 227,890 \\
\hline 2014 & 35 & 42 & 174,253 & 354,978 \\
\hline 2015 & 50 & 58 & 206,236 & 429,400 \\
\hline 2016 & 69 & 78 & 250,159 & 524,532 \\
\hline 2017 & 84 & 94 & 291,742 & 608,269 \\
\hline 2018 & 86 & 96 & 303,609 & 638,510 \\
\hline
\end{tabular}

As of 31 December 2018, there were 96 biogas plants in Poland, operated by 86 business entities. The total installed capacity in all plants was 101,767 MW [64]. Very high dynamics of growth were worth noting - not only in the number of production plants (from 8 to 96) but also the amount of biogas produced (over 8-fold increase in the period of 2011-2018). However, stagnation in the biogas market was observed in 2017-2018, which was primarily due to the lack of stability of the legal system regulating the renewable energy market. The prevailing business model is the operation of one plant by an entrepreneur functioning in this market in Poland. The largest entity producing agricultural biogas is Goodvalley Agro S.A. (it operates eight plants with a total technical capacity of 23,170 thousand $\mathrm{m}^{3} /$ year, i.e., approximately $6 \%$ of the total annual technical capacity of agricultural biogas plants in Poland-391,329 thousand $\mathrm{m}^{3} /$ year as of 5 January 2018). The locations of functioning plants producing agricultural biogas in Poland is shown in Figure 1. 


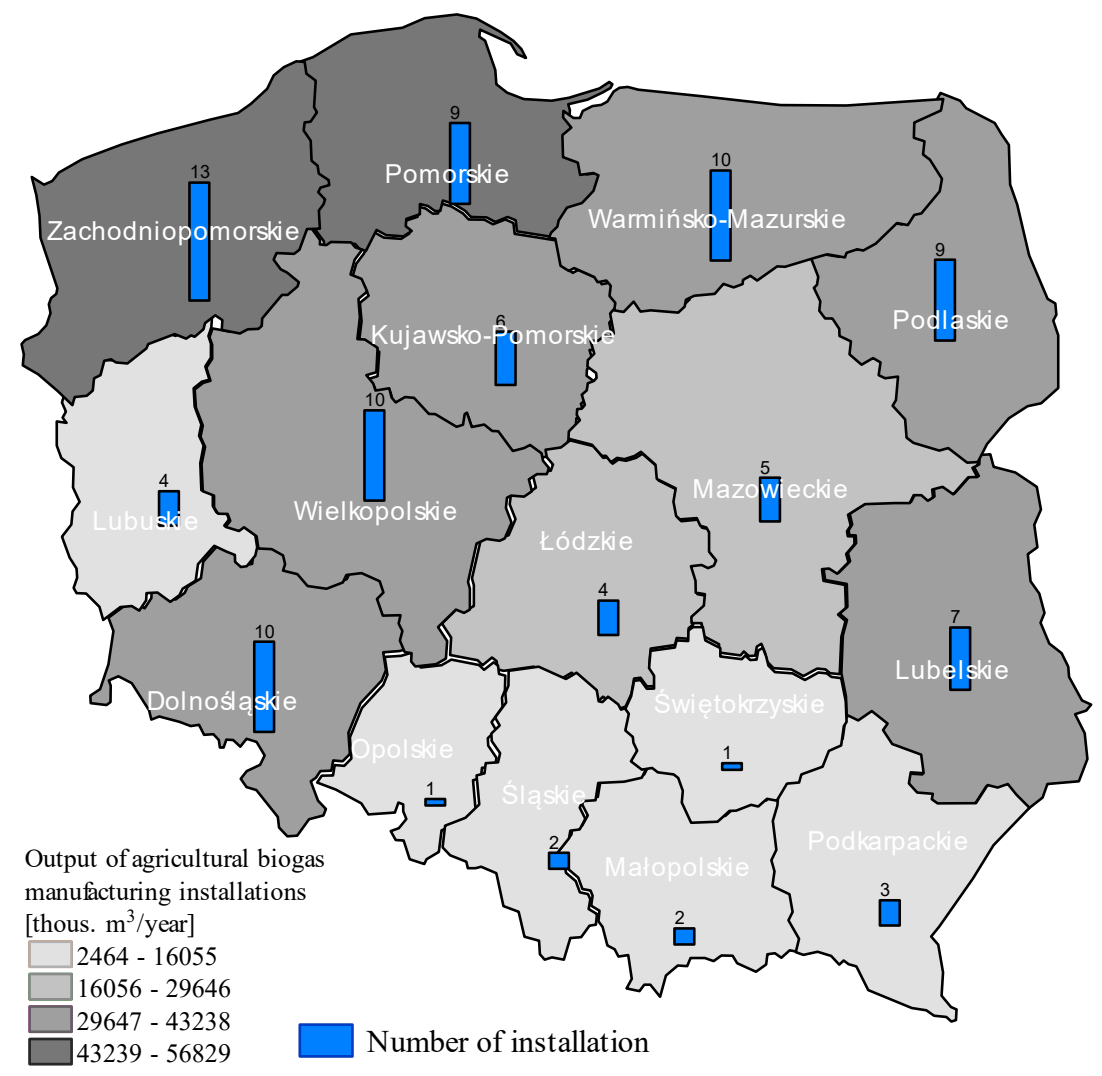

Figure 1. The number and capacities of agricultural biogas plants in Poland broken down by provinces (as of 24 January 2019) [65].

Considering the territorial distribution, the largest number of agricultural biogas plants in Poland (as of 31 December 2018) were in the Zachodniopomorskie province (13 plants), followed by the Warmińsko-Mazurskie, Dolnoślaskie and Wielkopolskie provinces (10 plants each), and the Pomorskie and Podlaskie provinces ( 9 agricultural biogas plants each). The least plants were in the south of the country. In total, 7 plants were operating in the Ślaskie, Małopolskie, and Podkarpackie provinces. In recent years, the agricultural biogas market in Poland has undergone significant changes in the structure of raw material consumption (Table 2).

Table 2. Consumption and structure of substrates to produce agricultural biogas in Poland in 2011-2018 [64].

\begin{tabular}{|c|c|c|c|c|c|c|c|c|c|}
\hline Specification & Units & 2011 & 2012 & 2013 & 2014 & 2015 & 2016 & 2017 & 2018 \\
\hline \multirow{2}{*}{ Liquid Manure } & $(\mathrm{Mg})$ & 265,961 & 349,173 & 455,583 & 574,069 & 598,963 & 774,997 & 807,223 & 757,555 \\
\hline & $(\%)$ & 56.66 & 38.07 & 28.94 & 27.00 & 24.11 & 23.98 & 21.26 & 18.94 \\
\hline $\begin{array}{c}\text { Residues from Fruit and } \\
\text { Vegetables }\end{array}$ & $(\%)$ & 2.34 & 9.39 & 17.06 & 16.73 & 19.89 & 20.59 & 19.94 & 19.24 \\
\hline Distillers Grains with Solubles & $(\mathrm{Mg})$ & 30,465 & 146,607 & 354,877 & 349,366 & 439,580 & 477,523 & 762,296 & 839,983 \\
\hline \multirow{2}{*}{ Maize Silage } & $(\mathrm{Mg})$ & 108,876 & 241,590 & 287,471 & 416,595 & 415,322 & 439,145 & 472,152 & 482,805 \\
\hline & $(\%)$ & 23.19 & 26.34 & 18.26 & 19.59 & 16.72 & 13.59 & 12.44 & 12.07 \\
\hline \multirow{2}{*}{ Bee Pulp } & $(\mathrm{Mg})$ & 6,922 & 37,082 & 101,661 & 189,811 & 189,016 & 222,157 & 280,209 & 291,768 \\
\hline & $(\%)$ & 1.47 & 4.04 & 6.46 & 8.93 & 7.61 & 6.87 & 7.38 & 7.29 \\
\hline
\end{tabular}


During the initial period of development of the agricultural biogas market in Poland, primarily liquid manure and maize silage were used as the main feedstock for production. In 2011, 265,960.79 $\mathrm{Mg}$ of liquid manure and $108,876.14 \mathrm{Mg}$ of maize silage were used to produce agricultural biogas, which accounted for $56.7 \%$ and $23.2 \%$ of the total volume of raw materials consumption, respectively. The share of liquid manure in the structure of raw material consumption has been decreasing year by year, and currently, the main raw materials for the production of agricultural biogas in Poland are distillers' grains with solubles (consumption in 2018 was $839,983.10 \mathrm{Mg}$ ). In the structure of raw material consumption in the period considered, there was a substantial increase in the volume of "fruit and vegetable residues" and "other" categories. In the latter category, consumption of the following raw materials, inter alia, was recorded in 2018: process sludge from the agri-food industry $(107,972.444$ $\mathrm{Mg})$, manure $(85,422.018 \mathrm{Mg})$, and expired food $(73,620.296 \mathrm{Mg})$. It is worth mentioning that the scale of food losses and waste in Poland is enormous. It is estimated that in quantitative terms, approximately 9 million tons of food is wasted annually in Poland [66,67]. In this context, further opportunities for the development of the agricultural biogas market can be sought in the area of raw material management (expired and unused food from commercial companies, mass catering establishments, households).

The intensive development of agriculture in Poland (high-input, resource-intensive farming systems) causes an increase in the supply of organic waste [3,68]. Given the large production volume, not only agriculture but also the agri-food industry can additionally supply biogas plants with feedstock. Hopes in this regard in Poland are seen in the poultry industry. Currently, Poland is a leader in poultry farming in the European Union. However, poultry litter is used for further processing only to a small degree. It is a raw material that enables high-volume biogas production, given its high content of organic matter [69]. According to literature data, poultry litter is characterized by a content of dry organic matter ranging from $63 \%$ to $80 \%$ dry mass (DM), biogas production at a level of $250-450 \mathrm{~m}^{3} / \mathrm{Mg}$ of dry organic mass, and methane content in biogas at a level of $60 \%$ (by volume) [70,71]. The problem with the use of poultry litter is from the high concentration of ammonium nitrogen, which can cause issues in the operation of a biogas plant. It can be solved using co-digestion [72], which requires new technological solutions [73-77]. Biogas plants have been perfected for decades, and yet the process of anaerobic digestion and biogas production from poultry litter is an important challenge from a research, economic, and environmental standpoint. It can be expected that technologies related to the economical use of this type of waste will continue to develop in the coming years.

Currently, in Poland, the total annual production potential for biogas (from substrates originating in the agricultural sector) is estimated to be from 2 to 5.5 billion $\mathrm{m}^{3}$ [78]. Igliński et al. (2020) calculated that the amount of energy that can be obtained from biogas in Poland is $131 \mathrm{PJ} / \mathrm{year}$ [79]. According to the data presented, the potential for agricultural biogas production is not used. So far, no stable support system has been set up to stimulate investments and guarantees for long-term investments in the area of agricultural biogas supply (purchase of energy, certificates of origin, etc.). The problem consists of using this potential and creating favourable conditions for development. Financial support for biogas production was insufficient, while rapidly changing regulations concerning renewable energy (including biogas plants) were not conducive to the use of potential opportunities.

The development of the agricultural biogas market in Poland should accelerate in the coming year's thanks to new regulations related to the organisation of the market. A system of green certificates has existed in Poland since 2005 [80]. Despite the good initial quotes for the certificates, their price has been decreasing dramatically over time. This led to a situation where plants ceased to be profitable. In turn, a feed-in tariff (FIT) system has been in place since 2018. This mechanism allows generators with plants with an installed capacity below $500 \mathrm{~kW}$ to start selling energy at a guaranteed price. Plants using the FIT system make it possible to receive $90 \%$ of the reference price for $1 \mathrm{MWh}$ from the obligated seller. The second support instrument introduced (feed-in premium, FIP) concerns plants with a capacity of not more than $1 \mathrm{MW}$ and not less than $500 \mathrm{~kW}$. The FIT system is simple and can be used by smaller plants (e.g., at agricultural holdings), where the owners have problems with waste 
management. The profitability can be improved by higher energy sales prices and financial support for investments. FIT or FIP tariffs are to be valid for 15 years, but not beyond the end of 2035 .

\section{Conclusions}

From 2011 to 2018, 88 new installations to produce agricultural biogas were created in Poland. The amount of biogas produced increased by 266.918 million $\mathrm{m}^{3}$ during the considered time range. For the needs of agricultural biogas plants in Poland from 2011-2018, a total of 18,600,441 Mg of raw materials was used, of which the most liquid manure $(4,583,524 \mathrm{Mg}$, i.e. $25 \%$ of the total raw material weight). Given the development of the agricultural biogas market, it was possible to increase the economic and environmental effects (in the context of the development of the circular economy). The construction of such facilities fits very well with the specificity of the Polish food economy. That is, the high potential resulting from natural factors and the level of development of agriculture (area of arable land, livestock population) and the developed agri-food industry (waste volume that can be used in biogas plants). Agricultural biogas plants can also be an important link around which local energy centres (clusters) will be created. Production activity in the field of agricultural biogas in Poland is still at a developmental stage, which is changing dynamically (i.e., the number of installations, volume of raw materials consumption, and changes in the structure of consumption).

The review of the literature and the results of analyses carried out indicate that agricultural biogas plants perform many economic, environmental, and social functions necessary for the development of a low-carbon economy in Poland. The development of the biogas market in Poland is closely related to legal and economic conditions, as well as administrative decisions regarding the location of biogas plants, and financial support in the areas of investments and operation (production), etc. Agricultural biogas plants are an essential element in the context of the evolution of the energy market in Poland towards the decentralized (distributed) model. An opportunity for further development of the agricultural biogas market is seen in new financial mechanisms that are beneficial for producers generating energy from agricultural biogas. This applies to already plants operating on the energy market and plants that are just starting up. Effective, economically efficient ways of collecting organic products (waste) from households of farmers and other rural residents for use in the production of biogas are also a challenge in the investigated area. In addition, poultry litter can be used on a larger scale as a substrate to produce agricultural biogas. This considers that Poland is currently the largest producer of poultry meat in the European Union. Utilization of the raw material resources that have not been used so far is a challenge from a technological (modernization of technology, efficiency, and performance issues), organizational (changes in the logistics process), and social (education, dissemination of good agricultural practices) standpoint.

Funding: This study was conducted and financed in the framework of the research project "The state and prospects of the development of low-carbon agriculture in Poland and the behaviour of agricultural producers", granted by the National Science Centre in Poland, program SONATA, grant No. 2016/21/D/HS4/00087.

Conflicts of Interest: The author declares no conflict of interest.

\section{References}

1. Nevzorova, T.; Karakaya, E. Explaining the drivers of technological innovation systems: The case of biogas technologies in mature markets. J. Clean. Prod. 2020, 259, 120819. [CrossRef]

2. Alexander, S.; Harris, P.; McCabe, B.K. Biogas in the suburbs: An untapped source of clean energy? J. Clean. Prod. 2019, 215, 1025-1035. [CrossRef]

3. Piwowar, A. Low carbon agriculture in Poland - theoretical and practical challenges. Pol. J. Environ. Stud. 2019, 28, 2785-2792. [CrossRef]

4. Kozłowski, K.; Dach, J.; Lewicki, A.; Malińska, K.; do Carmo, I.E.P.; Czekała, W. Potential of biogas production from animal manure in Poland. Arch. Environ. Prot. 2019, 45, 99-108.

5. Kucharski, P.; Białecka, B. Poultry manure as a substrate for agriculture and the chemical industry. Int. Multidiscip. Sci. GeoConf. SGEM 2019, 19, 611-618. 
6. Tłuczak, A. Potential and competitiveness of EU countries in terms of slaughter livestock production. Agric. Econ. Czech 2019, 65, 550-559. [CrossRef]

7. Wisniewski, P.; Kistowski, M. Local-level agricultural greenhouse gas emissions in Poland. Fresenius Environ. Bull. 2019, 28, 2255-2268.

8. Sulewski, P.; Majewski, E.; Was, A. Supporting sustainable agriculture: The potential to reduce GHG emissions-the case of agricultural biogas Production in Poland. Annu. Set Environ. Prot. 2018, 20, 662-680.

9. Jarosz, Z.; Faber, A. Ammonia emission from animal production in Poland on a regional scale. Ann. PAAAE 2019, 21, 117-124. [CrossRef]

10. Wysocka-Czubaszek, A.; Banaszuk, P.; Czubaszek, R. Methane and nitrous oxide emissions from agriculture in the Podlaskie voivodeship in years 1999-2015. Pol. J. Nat. Sci. 2018, 33, 433-453.

11. Piwowar, A. Challenges associated with environmental protection in rural areas of Poland: Empirical studies' results. Econ. Sociol. 2020, 13, 217-229. [CrossRef]

12. Piwowar, A. Attitudes and opinions of farmers in the context of environmental protection in rural areas in Poland. Environ. Monit. Assess. 2020, 192, 180. [CrossRef] [PubMed]

13. Kurowska, K.; Kryszk, H.; Marks-Bielska, R.; Mika, M.; Leń, P. Conversion of agricultural and forest land to other purposes in the context of land protection: Evidence from Polish experience. Land Use Policy 2020, 95, 104614. [CrossRef]

14. Frankowski, J. Attention: Smog alert! Citizen engagement for clean air and its consequences for fuel poverty in Poland. Energy Build. 2020, 207, 109525. [CrossRef]

15. Dzikuć, M. Problems associated with the low emission limitation in Zielona Góra (Poland): Prospects and challenges. J. Clean. Prod. 2017, 166, 81-87. [CrossRef]

16. Hernik, J.; Noszczyk, T.; Rutkowska, A. Towards a better understanding of the variables that influence renewable energy sources in eastern Poland. J. Clean. Prod. 2019, 241, 118075. [CrossRef]

17. Gnatowska, R.; Moryń-Kucharczyk, E. Current status of wind energy policy in Poland. Renew. Energy 2019, 135, 232-237. [CrossRef]

18. Jerez, S.; Tobin, I.; Turco, M.; Jiménez-Guerrero, P.; Vautard, R.; Montávez, J.P. Future changes, or lack thereof, in the temporal variability of the combined wind-plus-solar power production in Europe. Renew. Energy 2019, 139, 251-260. [CrossRef]

19. Igliński, B.; Buczkowski, R.; Iglińska, A.; Cichosz, M.; Piechota, G.; Kujawski, W. Agricultural biogas plants in Poland: Investment process, economical and environmental aspects, biogas potential. Renew. Sustain. Energy Rev. 2012, 16, 4890-4900. [CrossRef]

20. Budzianowski, W.M.; Chasiak, I. The expansion of biogas fuelled power plants in Germany during the 2001-2010 decade: Main sustainable conclusions for Poland. J. Power Technol. 2011, 91, 102-113.

21. Piwowar, A.; Dzikuć, M.; Adamczyk, J. Agricultural biogas plants in Poland-Selected technological, market and environmental aspects. Renew. Sustain. Energy Rev. 2016, 58, 69-74. [CrossRef]

22. Szymańska, D.; Lewandowska, A. Biogas power plants in Poland-Structure, capacity, and spatial distribution. Sustainability 2015, 7, 16801-16819. [CrossRef]

23. National Energy and Climate Plan for the years 2021-2030. Available online: https:/www.gov.pl/web/ aktywa-panstwowe/national-energy-and-climate-plan-for-the-years-2021-2030 (accessed on 30 March 2020).

24. Osička, J.; Kemmerzell, J.; Zoll, M.; Lehotský, L.; Černoch, F.; Knodt, M. What's next for the European coal heartland? Exploring the future of coal as presented in German, Polish and Czech press. Energy Res. Soc. Sci. 2020, 61, 101316. [CrossRef]

25. Rečka, L.; Ščasný, M. Brown coal and nuclear energy deployment: Effects on fuel-mix, carbon targets, and external costs in the Czech Republic up to 2050. Fuel 2018, 216, 494-502. [CrossRef]

26. Chen, C.; Xue, B.; Cai, G.; Thomas, H.; Stückrad, S. Comparing the energy transitions in Germany and China: Synergies and recommendations. Energy Rep. 2019, 5, 1249-1260. [CrossRef]

27. Muradin, M.; Foltynowicz, Z. Potential for producing biogas from agricultural waste in rural plants in Poland. Sustainability 2014, 6, 5065-5074. [CrossRef]

28. Lyytimäki, J. Renewable energy in the news: Environmental, economic, policy and technology discussion of biogas. Sustain. Prod. Consum. 2018, 15, 65-73. [CrossRef]

29. Lijó, L.; Lorenzo-Toja, Y.; González-García, S.; Bacenetti, J.; Negri, M.; Moreira, M.T. Eco-efficiency assessment of farm-scaled biogas plants. Bioresour. Technol. 2017, 237, 146-155. [CrossRef] 
30. European Biogas Association. Available online: https://www.europeanbiogas.eu/wp-content/uploads/2020/ 01/EBA-AR-2019-digital-version.pdf (accessed on 30 March 2020).

31. Banja, M.; Jégard, M.; Motola, V.; Sikkema, R. Support for biogas in the EU electricity sector-A comparative analysis. Biomass Bioenergy 2019, 128, 105313. [CrossRef]

32. Scarlat, N.; Dallemand, J.F.; Fahl, F. Biogas: Developments and perspectives in Europe. Renew. Energy 2018, 129, 457-472. [CrossRef]

33. Pablo-Romero, M.D.P.; Sánchez-Braza, A.; Salvador-Ponce, J.; Sánchez-Labrador, N. An overview of feed-in tariffs, premiums and tenders to promote electricity from biogas in the EU-28. Renew. Sustain. Energy Rev. 2017, 73, 1366-1379. [CrossRef]

34. IEA Bioenergy Task 37, Seoul, November 13-15, 2013, Country Report, Germany. Available online: http://www.biogas.cn/UpLoadEditor/file/20140116/20140116162141_1930.pdf (accessed on 12 February 2020).

35. Thrän, D.; Schaubach, K.; Majer, S.; Horschig, T. Governance of sustainability in the German biogas sector-Adaptive management of the Renewable Energy Act between agriculture and the energy sector. Energy Sustain. Soc. 2020, 10, 3. [CrossRef]

36. Theuerl, S.; Herrmann, C.; Heiermann, M.; Grundmann, P.; Landwehr, N.; Kreidenweis, U.; Prochnow, A. The future agricultural biogas plant in Germany: A vision. Energies 2019, 12, 396. [CrossRef]

37. Bernas, J.; Moudrý, J., Jr.; Kopecký, M.; Konvalina, P.; Štěrba, Z. Szarvasi-1 and Its Potential to Become a Substitute for Maize Which Is Grown for the Purposes of Biogas Plants in the Czech Republic. Agronomy 2019, 9, 98. [CrossRef]

38. Koryś, K.A.; Latawiec, A.E.; Grotkiewicz, K.; Kuboń, M. The Review of Biomass Potential for Agricultural Biogas Production in Poland. Sustainability 2019, 11, 6515.

39. Karaca, C. Determination of biogas production potential from animal manure and GHG emission abatement in Turkey. Int. J. Agric. Biol. Eng. 2019, 11, 205-210. [CrossRef]

40. Soyer, G.; Yilmaz, E. Waste Management in Dairy Cattle Farms in Aydin Region. Potential of Energy Application. Sustainability 2020, 12, 1614. [CrossRef]

41. McCarthy, B.; Kapetanaki, A.B.; Wang, P. Circular agri-food approaches: Will consumers buy novel products made from vegetable waste? Rural. Sociol. 2019, 28, 91-107. [CrossRef]

42. Antoniou, N.; Monlau, F.; Sambusiti, C.; Ficara, E.; Barakat, A.; Zabaniotou, A. Contribution to Circular Economy options of mixed agricultural wastes management: Coupling anaerobic digestion with gasification for enhanced energy and material recovery. J. Clean. Prod. 2019, 209, 505-514. [CrossRef]

43. Charkovska, N.; Horabik-Pyzel, J.; Bun, R.; Danylo, O.; Nahorski, Z.; Jonas, M.; Xiangyang, X. High-resolution spatial distribution and associated uncertainties of greenhouse gas emissions from the agricultural sector. Mitig. Adapt. Strateg. Glob. 2019, 24, 881-905. [CrossRef]

44. Dzikuć, M.; Piwowar, A. Ecological and economic aspects of electric energy production using the biomass co-firing method: The case of Poland. Renew. Sustain. Energy Rev. 2016, 55, 856-862. [CrossRef]

45. Dzikuć, M. Life cycle assessment technique as a support tool to determine the impact of thermal energy production on the environment. Przem. Chem. 2018, 97, 584-586. (In Polish) [CrossRef]

46. Piwowar, A.; Dzikuć, M. Outline of the economic and technical problems associated with the co-combustion of biomass in Poland. Renew. Sustain. Energy Rev. 2016, 54, 415-420. [CrossRef]

47. Energia ze źródeł odnawialnych w 2018 r. Available online: https://stat.gov.pl/download/gfx/ portalinformacyjny/pl/defaultaktualnosci/5485/10/2/1/energia_ze_zrodel_odnawialnych_w_2018.pdf (accessed on 3 January 2020).

48. Overview of electricity production and use in Europe. Available online: https://www.eea.europa.eu/dataand-maps/indicators/overview-of-the-electricity-production-2/assessment-4 (accessed on 8 March 2020).

49. Gawlik, L. The Polish power industry in energy transformation process. Miner. Econ. 2018, 31, $229-237$. [CrossRef]

50. Martinat, S.; Mintalova, T.; Dvořák, P.; Navratil, J.; Klusáček, P.; Kunc, J. Does rural space benefit from location of anaerobic digestion plants? Perspective of communal administration. Geogr. Cassoviensis 2013, 7, 41-49.

51. Pawłowski, W. Biogazownia jako element majacy pozytywny wpływ na zmiany środowiskowe przestrzeni wiejskich (Biogas plant as an element that has a positive influence on the environmental changes of rural space). Inżynieria Ekol. 2017, 18, 157-169. (In Polish) [CrossRef] 
52. De Menna, F.; Malagnino, R.A.; Vittuari, M.; Segrè, A.; Molari, G.; Deligios, P.A.; Solinas, S.; Ledda, L. Optimization of agricultural biogas supply chains using artichoke byproducts in existing plants. Agric. Syst. 2018, 165, 137-146. [CrossRef]

53. Blades, L.; Morgan, K.; Douglas, R.; Glover, S.; De Rosa, M.; Cromie, T.; Smyth, B. Circular biogas-based economy in a rural agricultural setting. Energy Proced. 2017, 123, 89-96. [CrossRef]

54. Siddiqui, S.; Zerhusen, B.; Zehetmeier, M.; Effenberger, M. Distribution of specific greenhouse gas emissions from combined heat-and-power production in agricultural biogas plants. Biomass Bioenerg. 2020, 133, 105443. [CrossRef]

55. Curkowski, A.; Oniszk-Popławska, A.; Haładyj, A.; Wybór, B.-P. Co Powinien Wiedzieć Każdy Obywatel (Biogas-A deliberate choice. What every citizen should know); Fundacja Instytut na rzecz Ekorozwoju: Warszawa, Poland, 2013; pp. 10-11. (In Polish)

56. Modica, M. Does the construction of biogas plants affect local property values? Econ. Lett. 2017, 159, 169-172. [CrossRef]

57. Scheutz, C.; Fredenslund, A.M. Total methane emission rates and losses from 23 biogas plants. Waste Manag. 2019, 97, 38-46. [CrossRef] [PubMed]

58. Jacyna, M.; Wasiak, M.; Lewczuk, K.; Karoń, G. Noise and environmental pollution from transport: Decisive problems in developing ecologically efficient transport systems. J. Vibroeng. 2017, 19, 5639-5655. [CrossRef]

59. Borowski, S.; Knopik, L.; Markiewicz-Patalon, M.; Brzostek, A. Assessment of transport substrates for selected agricultural biogas plant. In Proceeding of 6th International Conference on Trends in Agricultural Engineering, Prague, Czech Republic, 7-9 September 2016; pp. 76-80.

60. Sławiński, K.; Bujaczek, R.; Piskier, T. Ocena przydatności kalkulatorów biogazowni przy planowaniu budowy biogazowni rolniczej (Assessment of the usefulness of biogas calculators when planning the construction of agricultural biogas plants). Inżynieria Rol. 2012, 4, 369-375. (In Polish)

61. Pilarski, K.; Dach, J.; Janczak, D.; Zbytek, Z. Wpływ odległości transportowej na wydajność pracy agregatów i koszty zagospodarowania pofermentu z biogazowni rolniczej $1 \mathrm{MWel}$ (The influence of transport distance on tank efficiency and management costs of post-digestate from $1 \mathrm{MW}$ agricultural biogas plant). J. Res. Appl. Agric. Eng. 2011, 56, 109-113. (In Polish)

62. Piwowar, A. Development of the agricultural biogas market in Poland-Production volume, feedstocks, activities and behaviours of farmers. Probl. World Agric. 2019, 19, 88-97. [CrossRef]

63. Chodkowska-Miszczuk, J. Institutional Support for Biogas Enterprises-The Local Perspective. Quest Geogr. 2019, 38, 137-147. [CrossRef]

64. National Support Centre for Agriculture. Available online: http://bip.kowr.gov.pl/informacje-publiczne/ odnawialne-zrodla-energii/biogaz-rolniczy/dane-dotyczace-dzialalnosci-wytworcow-biogazu-rolniczegow-latach-2011-2018 (accessed on 30 March 2020).

65. National Support Centre for Agriculture. Available online: http://www.kowr.gov.pl/uploads/pliki/oze/ biogaz/Rejestr_wytw\%C3\%B3rc\%C3\%B3w_biogazu_rolniczego_z_dnia_24.01.2019_r.pdf (accessed on 11 January 2020).

66. Florkowski, W.J.; Us, A.; Klepacka, A.M. Food waste in rural households support for local biogas production in Lubelskie Voivodship (Poland). Resour. Conserv. Recycl. 2018, 136, 46-52. [CrossRef]

67. Marszałek, A. Czy możliwe jest przezwyciężenie problemu marnotrawstwa żywności? (Is it possible to solve the food waste problem?). Nierówności Społeczne Wzrost Gospod. 2018, 54, 474-485. (In Polish)

68. Pilarski, K.; Pilarska, A.A.; Boniecki, P.; Niedbała, G.; Durczak, K.; Witaszek, K.; Mioduszewska, N.; Kowalik, I. The Efficiency of Industrial and Laboratory Anaerobic Digesters of Organic Substrates: The Use of the Biochemical Methane Potential Correction Coefficient. Energies 2020, 13, 1280. [CrossRef]

69. Saad, M.F.M.; Rahman, N.A.A.; Yusoff, M.Z.M. Hydrogen and Methane Production from Co-digestion of Food Waste and Chicken Manure. Pol. J. Environ. Stud. 2019, 28, 2805-2814. [CrossRef]

70. Fugol, M.; Prask, H. Porównanie uzysku biogazu z trzech rodzajów kiszonek: Z kukurydzy, lucerny i trawy (Comparison of biogas yield from three types of silage: Maize, lucerne and grass silage). Inżynieria Rol. 2011, 9, 31-38. (In Polish)

71. Fugol, M.; Szlachta, J. Zasadność używania kiszonki z kukurydzy i gnojowicy świńskiej do produkcji biogazu (The reason for using corn and fermented liquid manure ensilage for biogas production). Inżynieria Rol. 2010, 1, 169-174. (In Polish) 
72. Sadecka, Z.; Suchowska-Kisielewicz, M. Co-fermentation of chicken manure. Annu. Set Environ. Prot. 2016, 18, 609-625. (In Polish)

73. Zhang, T.; Yang, Y.; Liu, L.; Han, Y.; Ren, G.; Yang, G. Improved biogas production from chicken manure anaerobic digestion using cereal residues as co-substrates. Energy Fuel 2014, 28, 2490-2495. [CrossRef]

74. Pečar, D.; Pohleven, F.; Goršek, A. Kinetics of methane production during anaerobic fermentation of chicken manure with sawdust and fungi pre-treated wheat straw. Waste Manag. 2020, 102, 170-178. [CrossRef] [PubMed]

75. Busato, C.J.; Da Ros, C.; Pellay, R.; Barbierato, P.; Pavan, P. Anaerobic membrane reactor: Biomethane from chicken manure and high-quality effluent. Renew. Energy 2020, 145, 1647-1657. [CrossRef]

76. Tańczuk, M.; Junga, R.; Kolasa-Więcek, A.; Niemiec, P. Assessment of the Energy Potential of Chicken Manure in Poland. Energies 2019, 12, 1244. [CrossRef]

77. Schommer, V.A.; Wenzel, B.M.; Daroit, D.J. Anaerobic co-digestion of swine manure and chicken feathers: Effects of manure maturation and microbial pretreatment of feathers on methane production. Renew. Energy 2020, 152, 1284-1291. [CrossRef]

78. Kurpaska, S.; Kiełbasa, P.; Sobol, Z. Innovative Methods of Obtaining Substrates and Pre-treatment in the Production of Biogas. In Renewable Energy Sources: Engineering, Technology, Innovation; Springer: Cham, Switzerland, 2020; pp. 199-207.

79. Igliński, B.; Piechota, G.; Iwański, P.; Skarzatek, M.; Pilarski, G. 15 Years of the Polish agricultural biogas plants: Their history, current status, biogas potential and perspectives. Clean Technol. Environ. 2020, 22, 281-307. [CrossRef]

80. Adamczyk, J.; Graczyk, M. Green certificates as an instrument to support renewable energy in Poland-Strengths and weaknesses. Environ. Sci. Pollut. Res. 2019, 27, 6577-6588. [CrossRef]

(C) 2020 by the author. Licensee MDPI, Basel, Switzerland. This article is an open access article distributed under the terms and conditions of the Creative Commons Attribution (CC BY) license (http://creativecommons.org/licenses/by/4.0/). 